\title{
SELEKSI BENIH TIRAM MUTIARA (Pinctada maxima) DARI HASIL PEMIJAHAN INDUK ALAM DENGAN KARAKTER NACRE PUTIH
}

\author{
Ida Komang Wardana, Sudewi, Apri I. Supii, dan Sari Budi Moria Sembiring \\ Balai Besar Penelitian dan Pengembangan Budidaya Laut \\ Jl. Br. Gondol Kec. Gerokgak Kab. Buleleng, Kotak Pos 140, Singaraja, Bali 81101 \\ E-mail: genta1190@yahoo.co.id
}

(Naskah diterima: 26 Juni 2013; Disetujui publikasi: 4 September 2013)

\begin{abstract}
ABSTRAK
Kualitas induk secara fenotip dan genotif berpengaruh terhadap kualitas benih tiram mutiara yang akan dihasilkan. Penggunaan induk yang berasal dari habitat yang berbeda dalam kegiatan pembenihan diharapkan dapat menghasilkan benih tiram mutiara dengan kualitas fenotip dan genotif yang baik. Salah satu sifat yang menarik untuk dijadikan target dalam program pemuliaan tiram mutiara adalah warna mutiara yang dihasilkan. Penelitian ini bertujuan untuk mengetahui kualitas benih tiram mutiara (Pinctada maxima) hasil pemijahan induk alam dengan karakter nacre putih dari tiga habitat yang berbeda dan mengetahui keragaan genetik induk (F0) dan turunannya (F1). Induk yang digunakan dalam penelitian ini adalah tiram dengan karakter nacre putih dari tiga lokasi perairan (Bali, Karawang, dan Dobo) serta dilakukan pemijahan dari masing-masing populasi tersebut. Keragaan genetik dari semua populasi dianalisa dengan menggunakan PCR RFLP. Hasil yang diperoleh menunjukkan bahwa masa inkubasi telur hasil pemijahan induk alam dengan karakter nacre putih terlihat lebih lama dibandingkan dengan tiram mutiara pada umumnya. Benih yang dihasilkan pertumbuhannya bervariasi, didominasi dengan benih berukuran sedang dengan sintasan berkisar 0,4-9\%. Keragaan genetik F0 dan F1 berdasarkan nilai heterozigositas, tiram dari perairan Bali menunjukkan nilai keragaman yang paling baik $(0,2726)$. Sementara karakter nacre dari benih yang diperoleh menunjukkan bahwa $48 \%$ memiliki nacre putih, $24 \%$ kuning dan warna lain sebanyak $28 \%$.
\end{abstract}

KATA KUNCI: seleksi benih, nacre putih, Pinctada maxima

ABSTRACT: Pearl oyster spat selection with white nacre character from artificial spawning of wild broodstock. By: Ida Komang Wardana, Sudewi, Apri I. Supii, and Sari Budi Moria Sembiring

Quality of broodstock, phenotypically, and genetically affects to the quality of pearl oyster seed to be produced. Broodstock that derives from the different habitat in the seeding activities is expected to produce pearl oyster seed with a good genetic quality. One of the interesting strait to be targeted in a pearl oyster breeding program is the color of pearls produced. Based on this, the purposes of this research were to know the pearl oyster (Pinctada maxima) seed quality from natural broodstock spawning with the character of white nacre from 3 different habitat and to know the genetic performance of parent (FO) and the first generation (F1). Pearl oyster broodstock used in this research have white nacre derive from three locations i.e. Bali, Karawang, and Dobo. Genetic character analysis was done by RFLP and PCR. The results showed that incubation period of egg spawned from natural broodstock that has white nacre was longer than that of common pearl oyster. The growth of seed produced varied, dominated by medium-sized seeds with survival rate ranged from 0.4-9\%. Genetic performance of FO and FI based on the value of heterozigosity showed that the pearl 
oyster from Bali has the highest diversity value (0.2726). Character of nacre from seeds produced showed that white colors achieved 48\%, $24 \%$ yellow and others colors (28\%).

\section{KEYWORDS: seed selection, white nacre, pearl oyster}

\section{PENDAHULUAN}

Berdasarkan morfologi cangkang, tiram mutiara Pinctada maxima yang dikenal sebagai penghasil south sea pearl diketahui ada empat tipe warna nacre yaitu putih (silver), emas (gold), abu-abu (grey) dan kuning (yellow) (Lind et al., 2009). Indonesia termasuk negara penghasil mutiara putih terbesar di dunia, menempati posisi ketiga setelah Australia dan Myanmar (Poernomo, 2008). Saat ini, dikembangkan program pemuliaan pada kegiatan budidaya yang diutamakan pada target khusus yaitu satu atau dua sifat yang memungkinkan untuk meningkatkan produktivitas dan memiliki nilai jual tinggi (Elliot, 2000). Salah satu sifat yang menarik untuk dijadikan target dalam program pemuliaan tiram mutiara adalah warna mutiara yang dihasilkan. Warna mutiara yang akan dihasilkan ditentukan oleh keragaman warna nacre tiram mutiara. Nacre adalah cangkang bagian dalam yang merupakan lapisan induk mutiara yang berkilau dengan warna putih keperakan. Wada (2000) menyatakan bahwa keragaman nacre pada tiram sangat penting dalam industri tiram mutiara, karena dengan keberagaman nacre tiram akan menghasilkan warna mutiara yang beragam yang diminati oleh pasar.

Tiram mutiara dengan nacre warna putih dan kuning paling banyak dibudidayakan, karena menghasilkan kualitas mutiara yang baik dengan ukuran yang relatif besar (Rose et al., 1990; Supii et al., 2009). Tiram dengan nacre putih menghasilkan mutiara warna putih, sementara tiram dengan nacre kuning menghasilkan mutiara warna kuning keemasan, akan tetapi mutiara warna putih memiliki harga jual yang lebih tinggi dibandingkan warna keemasan. Dalam proses insersi nukleus untuk memperoleh mutiara dengan warna putih diperlukan mantel sebagai saibo dari individu tiram dengan nacre putih, dan apapun tipe warna nacre tiram mutiara, apabila diimplant dengan saibo dari individu yang memiliki nacre putih akan tetap menghasilkan mutiara warna putih. Sementara individu tiram dengan nacre putih sangat jarang diperoleh dari alam, sehingga pemijahan induk tiram tersebut perlu dilakukan untuk membantu melestarikan dan membudidayakannya.

Namun dalam perkembangan budidaya tiram mutiara, masih ditemukan beberapa kendala antara lain penurunan kualitas produk mutiara, terjadinya kematian massal benih pada musim-musim tertentu dan lambatnya pertumbuhan benih. Kualitas induk secara fenotip dan genotif berpengaruh terhadap kualitas benih yang akan dihasilkan.

Dalam pembenihan, manajemen induk yang digunakan merupakan salah satu faktor penting yang harus diperhatikan. Penggunaan induk yang berasal dari habitat yang berbeda dalam kegiatan pembenihan diharapkan dapat menghasilkan benih tiram mutiara dengan kualitas fenotip dan genotif yang baik. Tujuan penelitian ini adalah untuk mengetahui kualitas dan menyeleksi benih tiram mutiara (Pinctada maxima) hasil pemijahan induk alam dengan karakter nacre putih dari tiga habitat yang berbeda serta mengetahui keragaan genetik induk (F0) dan turunannya (F1). Dengan demikian pembenihan secara terkontrol dan terprogram perlu diinisiasi untuk mendukung manajemen program pelestarian populasi yang lebih terarah, sehingga bermanfaat untuk pemuliaan tiram mutiara di masa yang akan datang.

\section{BAHAN DAN METODE}

\section{Koleksi Induk dan Pembenihan}

Langkah awal yang dilakukan dalam penelitian ini adalah koleksi induk alam (F0) yang memiliki karakter nacre putih dari wilayah perairan Bali, Karawang, dan Dobo. Aklimatisasi induk alam dilakukan secara terkontrol. Pemijahan dilakukan dengan menggunakan pasangan induk yang matang gonad dari masing-masing perairan. Hasil pemijahan tersebut, diharapkan memperoleh benih dari masing-masing pasangan induk sebesar $50 \%$. Telur dari hasil pemijahan tersebut dipelihara dalam hatcheri selama 45-50 hari dari stadia veliger (fase D) sampai spat. Selama masa pemeliharaan benih diberi pakan alami berupa Pavlova sp. (60\%), Isochrysis galbana (20\%), Chaetocheros amami (10\%), dan Nannoclorop- 
sis (10\%). Pergantian air media pemeliharaan dilakukan setiap lima hari sekali atau disesuaikan dengan kondisi larva. Parameter lingkungan yang dipantau selama masa pemeliharaan benih meliputi suhu, $\mathrm{pH}$, dan salinitas. Spat yang diperoleh setelah mencapai ukuran 2-3 mm ditebar di laut untuk pembesaran. Spat yang masih menempel pada kolektor ditebar dalam wadah kerangka besi dengan ukuran 50 $\mathrm{cm} \times 35 \mathrm{~cm} \times 75 \mathrm{~cm}$. Setiap 2-3 minggu sekali waring yang membungkus wadah dibersihkan dari kotoran dan biofouling yang menempel untuk membantu mempermudah spat dalam menyaring makanan. Benih dengan ukuran 1 $2 \mathrm{~cm}$ dipotong bisusnya dan dipindah dalam pocket benih untuk mempercepat pertumbuhan. Setelah benih mencapai ukuran $6 \mathrm{~cm}$ atau warna nacre sudah dapat dibedakan, dilakukan sampling untuk mengetahui persentase benih dengan nacre putih atau warna lain. Benih yang sudah terseleksi dipelihara lebih lanjut untuk pemantauan kualitas hingga memenuhi syarat sebagai calon induk.

\section{Analisis Keragaan Genetik}

Jaringan dari induk dan benih diambil sebagai bahan analisis untuk mengetahui keragaan genetik masing-masing 15 ekor. Jaringan mantel yang diambil kemudian diekstraksi DNA-nya menggunakan metode Ovenden (2000) yang sudah dimodifikasi. Sampel daging dihancurkan dengan chelex 100 in TE buffer, ditambahkan protein kinase (Merk) dan diinkubasi pada suhu $55^{\circ} \mathrm{C}$ selama 2,5 jam. Selanjutnya sampel yang sudah hancur, diinkubasi kembali selama delapan menit pada suhu $89^{\circ} \mathrm{C}$. Langkah akhir dilakukan sentrifugasi dengan kecepatan 13.000 rpm selama 5-6 menit, sehingga terbentuk dua lapisan dan bagian supernatant-nya merupakan genom DNA dari sampel tiram mutiara. Hasil ekstraksi dipurifikasi menggunakan High Pure Purification kit (Roche) dan selanjutnya diukur tingkat kemurnian DNAnya dengan Gene Quant Machine. Tahap berikutnya adalah amplifikasi DNA dengan menggunakan primer universal Cytochrome Oxidase I (COI) forward: 5"- ATA ATG ATA GGA GGR TTT GG-3" dan reverse 5"-GCT CGT GTR CTA CRT CCA T-3" (Williams \& Benzie, 1997). Amplifikasi dilakukan dengan menggunakan metode Polymerase Chain Reaction (PCR) dengan komposit premiks yaitu $\mathrm{dd}_{2} \mathrm{O}$ 21,25 $\mathrm{LL}$, primer forward, reverse masingmasing $0,625 \mu \mathrm{L}$ dan $2,5 \mu \mathrm{L}$ genom DNA yang dicampur pada tube Ready to go (GE healthcare). Program yang digunakan berdasarkan
Benzie et al, 2003 yaitu tahap denaturasi pada suhu $94^{\circ} \mathrm{C}$ selama satu menit, annealing pada suhu $45^{\circ} \mathrm{C}$ selama satu menit dan extension selama satu menit sebanyak 30 siklus pada suhu $72^{\circ} \mathrm{C}$. Setelah proses amplifikasi semua sampel sempurna, dilakukan digesti dengan beberapa enzim restriksi Dde I, Taq I, dan Msp I (Biolabs) untuk mengetahui variasi genetik dan tingkat heterozigositas induk dan benih hasil pemijahan. Hasil restriksi dipisahkan secara elektroforesis dengan menggunakan agarose gel 2\% dalam Tris Boric-EDTA (TBE) buffer dan didokumentasikan pada gel doc polaroid dengan UV transilluminator. Hasil fragmentasi selanjutnya dianalisis menggunakan UPGMA (Unweighted Pair Group Methode by Average) dalam software TFPGA (Bermingham, 1990). Parameter yang diamati meliputi: karakter fenotip benih yang dihasilkan, sintasan benih (SR), keragaan genetik induk (FO) dan benih (F1) yang diukur berdasarkan tingkat heterozigositas.

\section{HASIL DAN BAHASAN}

\section{Pengamatan Induk}

Berdasarkan pengamatan morfologi induk dari tiga lokasi perairan, ditemukan beberapa perbedaan secara visual antara lain: warna cangkang luar, ketebalan cangkang dan bentuk tubuh. Induk dari Bali terlihat berwarna cream terang dengan bentuk tubuh agak bulat dan cangkang tebal. Sedangkan induk dari perairan Karawang memiliki warna cangkang coklat hijau dengan garis-garis cangkang nampak jelas, cangkang tipis dan bentuk tubuh membulat. Sementara induk dari perairan Dobo (Maluku) bentuk tubuhnya bulat lonjong dengan warna cangkang cokelat gelap dan cangkang halus tebal (Gambar 1). Ditinjau dari segi panjang, lebar dan bobot tubuh induk alam tiram mutiara dari masing-masing lokasi tidak menunjukkan perbedaan yang signifikan (Tabel 1). Berdasarkan dari spesifikasi tersebut, tiram-tiram yang ada sudah memenuhi syarat sebagai induk dan dapat dipijahkan. Akan tetapi ada beberapa hal yang perlu diperhatikan sebelum induk mulai dipijahkan antara lain induk dalam kondisi sehat, cangkang berwarna terang, tidak rusak atau cacat dan tingkat kematangan gonadnya pada stadia matang penuh (fase IV). Slamet et al. (1997), Anonim (2008). Dari pemantauan terhadap kondisi kesehatan induk, terlihat bahwa induk dari perairan Karawang menunjukkan kondisi kurang sehat, karena mantel nampak lemah dan 

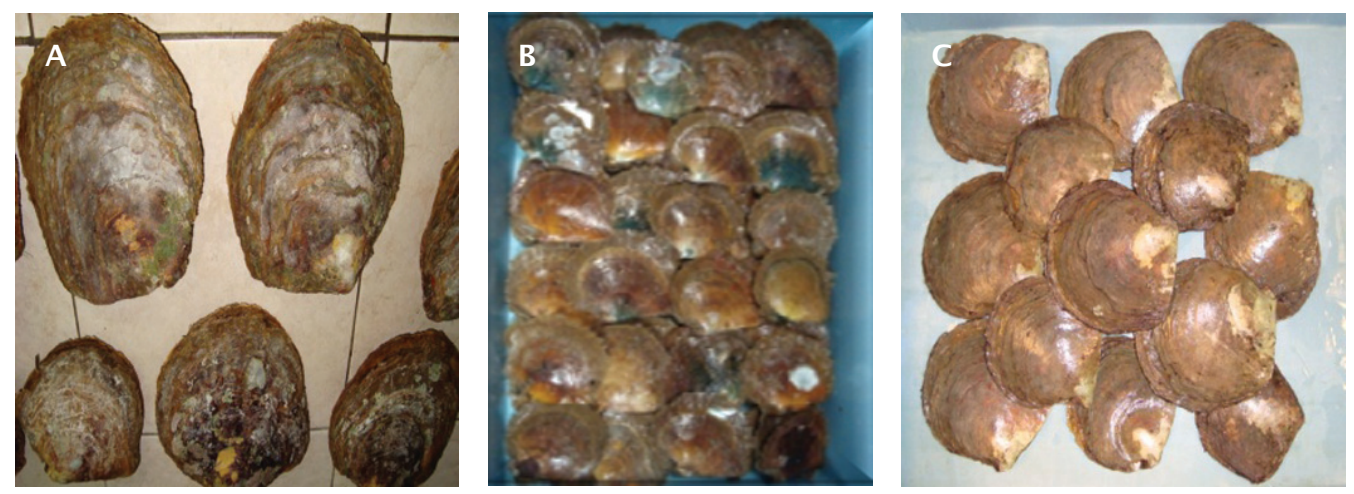

Gambar 1. Morfologi induk alam tiram mutiara (Pinctada maxima) dari tiga perairan, berturutturut Bali (A), Karawang (B), dan Dobo (C)

Figure 1. Morphology of natural broodstock of pearl oyster (Pinctada maxima) from three waters areas, Bali (A), Karawang (B), and Dobo (C) respectively

Tabel 1. Panjang, lebar, dan bobot tubuh induk tiram mutiara (Pinctada maxima) dari tiga lokasi perairan

Table 1. Length, width, and body weight of pearl oyster (Pinctada maxima) from three locations

\begin{tabular}{lccc}
\hline \multirow{2}{*}{$\begin{array}{c}\text { Parameter } \\
\text { Paramet ers }\end{array}$} & \multicolumn{3}{c}{ Lokasi (Locations) } \\
\cline { 2 - 4 } & Bali & Karawang & Dobo \\
\hline Panjang (Length) (cm) & $15.9 \pm 1.7$ & $15.9 \pm 1.6$ & $14.7 \pm 1.2$ \\
Lebar (Width) (c m) & $10.9 \pm 0.9$ & $11.9 \pm 1.5$ & $12.1 \pm 0.9$ \\
Bobot (Weight) (g) & $487 \pm 107.2$ & $464 \pm 131.2$ & $421 \pm 37.5$ \\
\hline
\end{tabular}

banyak mengalami kematian selama proses adaptasi pada perairan Gondol. Dari 103 ekor induk asal Karawang yang dikoleksi, 57 ekor mati (Tabel 2) dan induk-induk tersebut cukup sulit untuk matang gonad. Sementara induk dari Bali dan Dobo, selama masa pemijahan dan pemeliharaan di laut, relatif mudah matang gonad walaupun hasil yang diperoleh belum maksimal. Dengan demikian untuk mengoptimalkan hasil yang diharapkan, penambahan jumlah induk dengan karakter nacre putih perlu dilakukan untuk meningkatkan jumlah benih yang dihasilkan, sehingga proses seleksi mudah dilakukan dan data yang diperoleh lebih akurat.

\section{Pemantauan Pemijahan}

Seleksi benih tiram mutiara dengan nacre putih, berdasarkan dari hasil pemantauan pemijahan dan pemeliharaan larva diperoleh data bahwa pemijahan induk tiram mutiara tidak dapat berlangsung sepanjang tahun, sangat tergantung musim, umur, dan kondisi kesehatan induk, serta suhu lingkungan perairan. Pemijahan induk dari perairan Bali berlangsung sebanyak lima kali yaitu pada bulan Februari, April, Juni, Agustus, dan September. Sementara dari perairan Karawang hanya memijah satu kali pada bulan Maret dan dari perairan Dobo sebanyak tiga kali dari bulan Juli, September, dan Oktober. Dari semua pemijahan tersebut, banyaknya induk yang matang gonad juga sangat bervariasi, tidak semua induk menunjukkan tingkat kematangan gonad yang baik. Dari jumlah total induk yang ada, hanya $10 \%$ yang menunjukkan tingkat kematangan gonad sempurna, akan tetapi setelah dipijahkan secara alami tidak semua induk dapat memijah dengan maksimal. Bahkan ada beberapa induk yang mengabsorbsi gonadnya, sehingga tidak dapat dipijahkan dan dikembalikan ke laut. Faktor yang dianggap paling berpengaruh terhadap kematangan 
Tabel 2. Pemijahan induk alam tiram mutiara (Pinctada maxima) dengan nacre putih dari tiga lokasi perairan

Table 2. Spawning of pearl oyster (Pinctada maxima) with the white nacre from three locations

\begin{tabular}{lccc}
\hline \multirow{2}{*}{ Parameter } & \multicolumn{3}{c}{ Asal induk (Broodstock origin) } \\
\cline { 2 - 4 } & Bali & Karawang & Dobo \\
\hline $\begin{array}{l}\text { Jumlah induk (ekor) } \\
\text { Number of broodstock (ind.) }\end{array}$ & 68 & 103 & 31 \\
$\begin{array}{l}\text { Frekuensi pemijahan (kali) } \\
\text { Spawning frequence (time) }\end{array}$ & 5 & 1 & 3 \\
\hline
\end{tabular}

\begin{tabular}{|c|c|c|c|}
\hline & \multicolumn{3}{|c|}{ Jumlah larva (Ekor) (Number of larvae) (Ind.) } \\
\hline & Bali & Karawang & Dobo \\
\hline Pemijahan (Spawning) I & $8,335,000$ & 22 & 725.6 \\
\hline Pemijahan(Spawning) II & 325 & - & 479.5 \\
\hline Pemijahan (Spawning) III & $\begin{array}{c}28,000,000 \text { (Mati umur D23) } \\
(\text { Dead at D23) }\end{array}$ & - & $\begin{array}{l}\text { 28,000 (Mati umur D7) } \\
\text { (Dead at D7) }\end{array}$ \\
\hline Pemijahan (Spawning) IV & 36 & - & - \\
\hline Pemijahan (Spawning) V & $8,317,000$ & - & - \\
\hline Benih $(F r y)(1-2 \mathrm{~cm})$ & 11.3 & - & 1,700 \\
\hline Benih $(F r y)(3-4 \mathrm{~cm})$ & 789 & 43 & - \\
\hline Benih $(F r y)>4 \mathrm{~cm}$ & 143 & - & - \\
\hline $\begin{array}{l}\text { Jumlah total benih } \\
\text { Total of fry }\end{array}$ & 12,232 & 43 & 1,700 \\
\hline $\begin{array}{l}\text { Jumlah induk yang mati } \\
\text { Mortality of broodstock }\end{array}$ & 26 & 57 & 3 \\
\hline Keterangan (Remark) & \multicolumn{3}{|c|}{$\begin{array}{l}\text { Karena pe mijahan masing-masing populasi tidak berlangsung } \\
\text { pada waktu yang sama, maka benih dari populasi Karawang dan } \\
\text { Dobo pada akhir penelitian hanya berada pada satu ukuran } \\
\text { The fry from Dobo and Karawang were uniform in size, because } \\
\text { the spawning periods from each population were not } \\
\text { simultaneously }\end{array}$} \\
\hline
\end{tabular}

gonad induk tiram alam berdasarkan pengamatan antara lain: umur, pakan alami yang tersedia, dan kondisi suhu air pada perairan tersebut. Menurut Dhoe et al. (2001); Anonim (2008), menyatakan bahwa umur tiram yang siap memijah adalah 2-2,5 tahun dengan ukuran panjang cangkang berkisar antara $15-16 \mathrm{~cm}$ dan disarankan menggunakan induk dari hasil budidaya. Sementara untuk pakan alami, sangat tergantung pada tingkat kesuburan perairan tersebut. Pada umumnya tiram sebagai organisme filter feeder relatif mudah dalam menyaring makanan yang ada di lingkungan- nya kecuali jika dalam kondisi stres. Pengaruh dari suhu perairan terlihat pada lambatnya pertumbuhan benih dan jarangnya induk betina yang matang gonad (Hamzah, 2007)

Ditinjau dari performa pemijahan, induk Bali dan induk Dobo menunjukkan respon yang paling baik. Dari lima kali pemijahan induk Bali hanya pada pemijahan yang ketiga benih yang dihasilkan mengalami kematian pada umur 23 hari (D23), sedangkan benih dari pemijahan yang lainnya dapat bertahan hidup sampai pembesaran di laut, walaupun dengan sintasan yang cukup rendah (Gambar 2). Demikian 


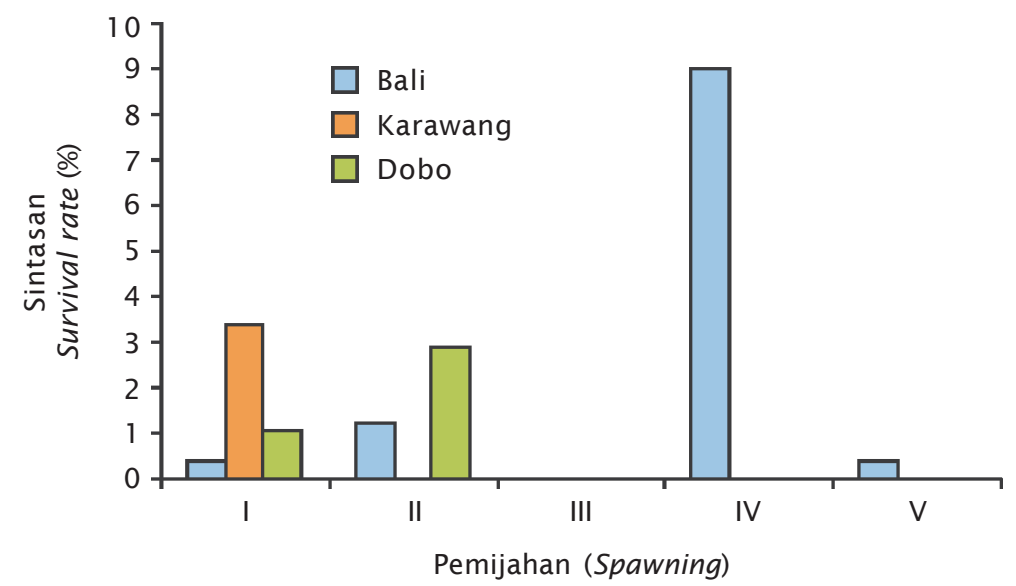

Gambar 2. Sintasan benih tiram mutiara masing-masing pemijahan dari ketiga lokasi induk alam

Figure 2. Survival rate of pearl oyster seed at each spawning from three locations of natural broodstock

halnya pada induk dari perairan Dobo pada pemijahan ketiga, benih yang dihasilkan pada umur tujuh hari (D7) mengalami kematian. Hal tersebut disebabkan oleh induk dari Dobo masih dalam proses adaptasi karena mulai masuk Balai Besar Penelitian dan Pengembangan Budidaya Laut pada bulan Juli dan pemijahan dilakukan selang tiga minggu sekali. Selain itu juga karena pengaruh suhu perairan yang relatif rendah pada bulan tersebut. Benih yang diperoleh dari hasil pemijahan tersebut setelah menjadi spat relatif sedikit. Pada pemijahan pertama diperoleh spat sebanyak 1200 ekor dan pada pemijahan kedua sebanyak 500 ekor. Sedangkan induk dari perairan Karawang pada saat memijah, sel telur dan sperma yang keluar relatif sedikit yang berasal dari satu induk jantan dan satu induk betina. Setelah dilakukan sampling dan pengamatan, diketahui telur yang berhasil dibuahi sebanyak 40.000 butir dan yang berhasil menjadi veliger (tahap D) sebanyak 22.000 ekor (daya tetas 55\%). Jumlah akhir benih yang diperoleh dari induk Karawang pada stadia spat sebanyak 273 ekor (Gambar 3). Rendahnya jumlah spat yang diperoleh dari pemijahan induk Karawang, kemungkinan dipengaruhi oleh kondisi kesehatan induk, karena pada saat pemijahan berlangsung, induk masih dalam tahap adaptasi pada lingkungan baru dan stres karena proses pengangkutan yang relatif lama ( \pm 12 jam). Setelah umur 2 bulan, 4 bulan dan 6 bulan adaptasi pada lingkungan perairan di Gondol, observasi dilakukan kembali terhadap tingkat kematangan gonadnya. Dari 100 ekor induk yang ada hanya 2-3 ekor induk yang menunjukkan matang gonad. Akan tetapi setelah dilakukan pemijahan, induk-induk tersebut tidak memberikan respon yang positif, sehingga pemijahan tidak dapat berlangsung dan induk dikembalikan ke laut. Berdasarkan hal tersebut, dapat dikatakan bahwa induk dari perairan Karawang belum siap memijah karena mungkin umur masih muda, kemampuan adaptasi pada daerah baru kurang baik dan kurangnya respon terhadap rangsangan pemijahan.

\section{Pengamatan Benih}

Benih yang dihasilkan dari hasil pemijahan secara keseluruhan sangat bervariasi. Berdasarkan pengamatan pada setiap periode pemeliharaan benih, ditemukan perbedaan waktu perkembangan embrio pada pemijahan induk Bali. Pada bulan Maret, perkembangan stadia embrio masih normal dengan masa pembelahan telur menjadi morula dibutuhkan waktu 1-1,5 jam. Sementara pemijahan pada Mei, Juni, dan Juli, masa inkubasinya cukup lama (lebih dari 2 jam) dan telur yang dihasilkan sebagian besar tidak dibuahi, sehingga tidak bisa membelah sempurna menjadi trokofor. Di samping hal tersebut, pada bulan yang sama fase veliger menjadi fase mata hitam (eye spot) dibutuhkan waktu yang relatif lama yaitu sekitar 20-24 hari, sementara menurut Tin Tun \& Winanto (1988), Haws \& Ellis, (2000), menya- 


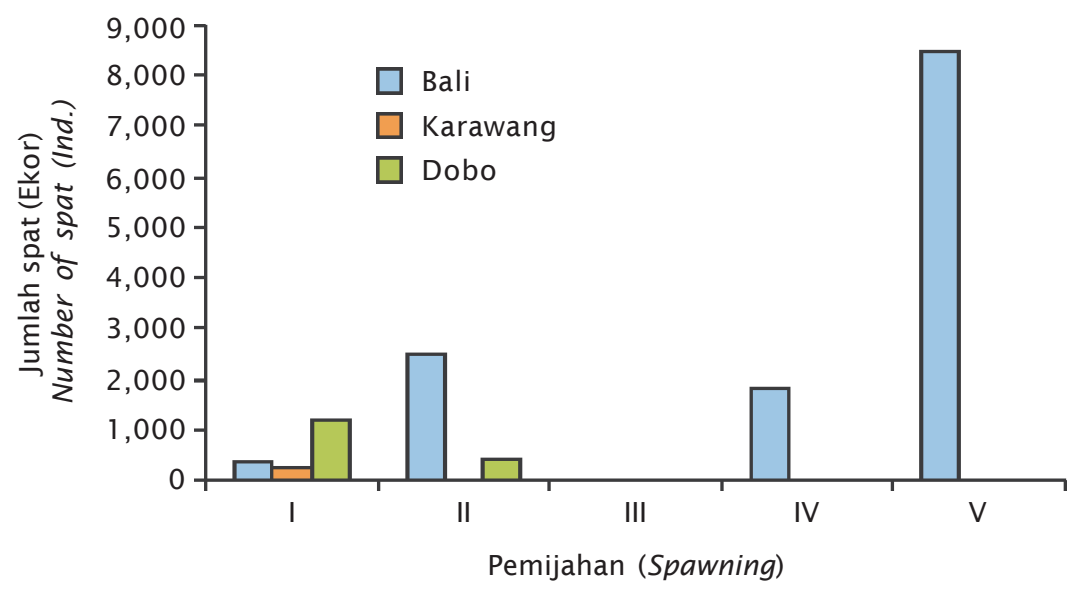

Gambar 3. Jumlah spat yang sudah ditebar di laut dari masing-masing hasil pemijahan induk alam tiram mutiara

Figure 3. Number of spat stocked at sea from each of spawning from the natural broodstock of pearl oyster

takan bahwa fase eye spot dapat terbentuk pada hari ke-16 dan 17. Akan tetapi pada pemijahan bulan Agustus, September, dan Oktober, fase tersebut berlangsung normal bahkan ada beberapa larva yang sudah memasuki fase pediveliger. Lambatnya stadia perkembangan larva pada kegiatan penelitian ini dipengaruhi oleh faktor lingkungan salah satunya suhu. Suhu air pada media pemeliharaan benih pada bulan Mei, Juni, dan Juli relatif rendah yaitu berkisar antara $25^{\circ} \mathrm{C}-26^{\circ} \mathrm{C}$ (Gambar 4). Rendahnya suhu air akan mempengaruhi proses metabolisme dalam tubuh yang berdampak pada lambatnya perubahan stadia (metamorfosis) dan pertumbuhan benih (Anonim, 2008). Menurut Ito (1996); Dhoe at al. (2001), menyatakan bahwa suhu yang memenuhi syarat untuk pemeliharaan benih tiram mutiara adalah berkisar antara $28^{\circ} \mathrm{C}-30,5^{\circ} \mathrm{C}$.

Benih tiram mutiara ( $F 1)$ yang sudah ditebar di laut, secara morfologi pada stadia spat antara populasi 1 dengan populasi yang lain tidak dapat dibedakan. Spat nampak berwarna abu-abu dengan ukuran yang bervariasi (1$3 \mathrm{~mm}$ ). Setelah berumur satu bulan di laut, dengan penambahan panjang nacre antara $1-1,5 \mathrm{~cm} /$ bulan, spat nampaknya mengalami perubahan warna yang didominasi dengan warna abu-abu, coklat, coklat muda dan kehijauan atau hijau gelap. Hal tersebut dapat dikatakan sebagai indikator bahwa benih dalam kondisi sehat dan pakan yang tersedia di perairan mencukupi untuk mendukung pertumbuhan benih. Akan tetapi pada tahap ini, benih relatif riskan dan mudah mengalami kematian akibat pengaruh dari goncangan lingkungan dan proses adaptasi dari hatcheri ke lingkungan air laut. Dengan demikian pemantauan rutin pada tahap tersebut sangat penting dilakukan untuk menghindari tingkat kematian yang tinggi. Dari jumlah benih yang dihasilkan pada penelitian ini, benih (spat) yang jumlahnya cukup banyak adalah benih dari populasi Bali 12.232 ekor, turunan populasi Dobo 1700 ekor dan turunan Karawang yang tersisa 43 ekor dengan ratarata ukuran panjang berkisar antara $1-3 \mathrm{~cm}$ (Tabel 2). Akan tetapi dilihat dari tingkat sintasan (SR) benih sampai tahap spat secara keseluruhan sangat rendah berkisar antara 0,1\%-9\% (Gambar 2). Menurut para praktisi hatcheri tiram mutiara yang ada di Bali dan NTB rata-rata sintasan yang diperoleh berkisar antara 1\%-1 1\% dan hal tersebut dihitung berdasarkan perbandingan antara jumlah spat yang diperoleh dengan hasil sampling jumlah larva pada stadia pediveliger (komunikasi pribadi). Sementara pada kegiatan ini, pemantauan terhadap penurunan jumlah larva selama masa pemeliharaan di hatcheri, diamati dari stadia veliger (tahap D) sampai menjadi spat ( \pm 45-50 hari). Berdasarkan dari pengamatan tersebut, dapat dikatakan bahwa selama masa pergantian stadia terjadi penurunan jumlah benih yang hidup berkisar antara 20\%$40 \%$. Misalnya benih turunan induk Bali pada pemijahan yang terakhir diperoleh telur yang 


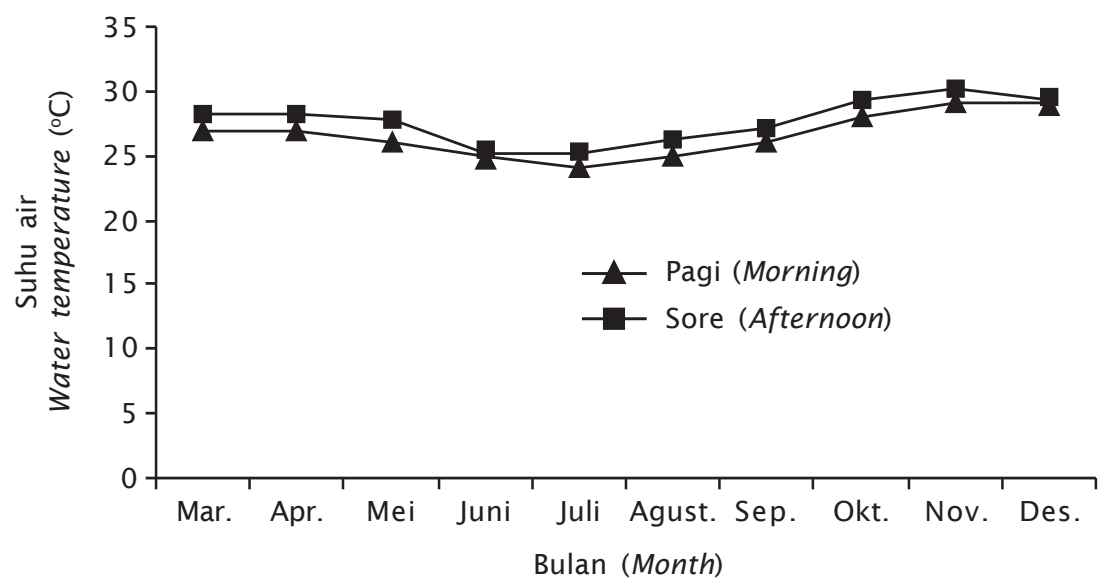

Gambar 4. Rata-rata suhu air pada bak pemeliharaan larva tiram mutiara

Figure 4. Average of water temperature in larva rearing tank

berhasil dibuahi sebanyak 18.975.000 dengan daya tetas $44 \%$, jumlah benih pada umur D1, 8.317 .000 ekor, setelah enam hari menjadi 8.184.000 ekor, kemudian umur sepuluh hari menjadi 7.219 .500 ekor, hari ke-16 berkurang menjadi 3.897.000 ekor dan pada hari ke-20 sebelum dipasang kolektor menjadi 1.798.000 ekor. Sementara jumlah setelah memasuki stadia spat ( \pm 45 hari) hanya diperoleh 8.500 ekor dengan sintasan $0,1 \%$.

Data hasil seleksi nacre dari benih yang diperoleh berdasarkan dari sampling menunjukkan bahwa $48 \%$ benih memiliki nacre putih, $24 \%$ warna kuning dan warna lain sebanyak $28 \%$. Sementara menurut informasi bahwa persentase warna nacre benih dari hasil pemijahan induk dengan karakter nacre putih dapat terlihat setelah benih berukuran di atas $6 \mathrm{~cm}$ dengan perbandingan 70\% memiliki warna nacre putih dan $30 \%$ menunjukkan warna yang lain (komunikasi pribadi). Berdasarkan hal tersebut, dapat dikatakan bahwa di alam populasi tiram mutiara sudah membawa gen warna nacre baik kuning maupun putih, akan tetapi populasi nacre putih di alam termasuk jarang dibandingkan dengan populasi nacre kuning (Gambar 5). Dengan demikian pemijahan yang terkontrol sangat perlu diterapkan untuk mempermudah melakukan perbaikan terutama dalam menghasilkan benih dengan persentase karakter nacre putih lebih tinggi.

\section{Keragaan Genetik}

Pemantauan keragaan genetik terhadap tiram mutiara dari ketiga lokasi daerah pe- nangkapan diharapkan memberikan pedoman dalam menentukan sumber induk yang memiliki karakter genetik yang baik. Berdasarkan dari hasil amplifikasi dengan menggunakan primer COI (Cytochrome Oxydase I), didapatkan bahwa mtDNA pada tiram mutiara (Pinctada maxima) menghasilkan fragment DNA tunggal berukuran 700 bp pada semua populasi, baik pada induk alam maupun pada turunannya (F1) (Gambar 6). Hal tersebut mengindikasikan bahwa hewan uji tersebut merupakan spesies yang sama. Untuk mengetahui adanya variasi masing-masing populasi, dilakukan pemotongan sequen mtDNA yang teramplifikasi menggunakan tiga jenis enzyme restriksi. Dari hasil pemotongan tersebut, terlihat ada dua tipe pemotongan yaitu tipe monomorfik (Dde I dan Taq I) dan penggunaan enzyme Msp I memberikan pemotongan tipe polymorfik (Gambar 7). Penggunaan enzyme Dde I menunjukkan tiga sisi pemotongan pada bobot molekul 160, 200, dan 400 bp, demikian juga halnya pada penggunaan enzyme restriksi Taq I (Tabel 3, Gambar 7). Berdasarkan dari hasil pemotongan tersebut, enzyme Msp $I$ yang memberikan tipe pemotongan yang bervariasi dan sementara dapat digunakan sebagai marker untuk identifikasi variasi populasi tiram mutiara jenis Pinctada maxima. Di samping itu, perlu penggunaan enzyme restriksi yang lain untuk mendapatkan hasil yang lebih akurat. Seperti pada pemantauan karakteristik genetik tiram mutiara jenis $P$. margaritifera yang ada di perairan Indonesia restriksi mtDNA menggunakan lima jenis enzyme pemotongan yaitu Fok I, Hae III, Nla IV, 

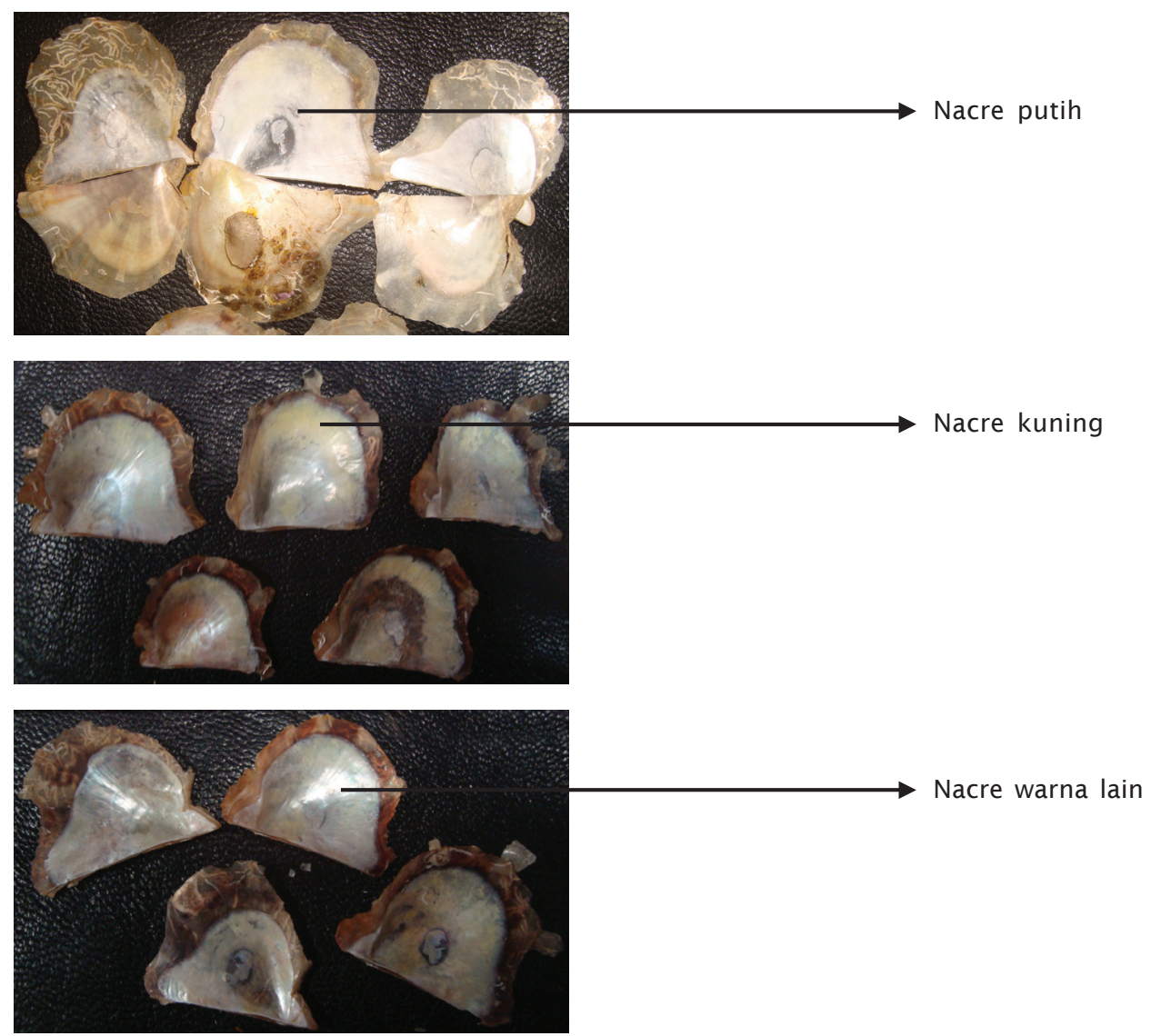

Gambar 5. Tipe warna nacre benih tiram mutiara dari hasil pemijahan induk alam

Figure 5. Color type of nacre of pearl oyster seed from spawning of natural broodstock

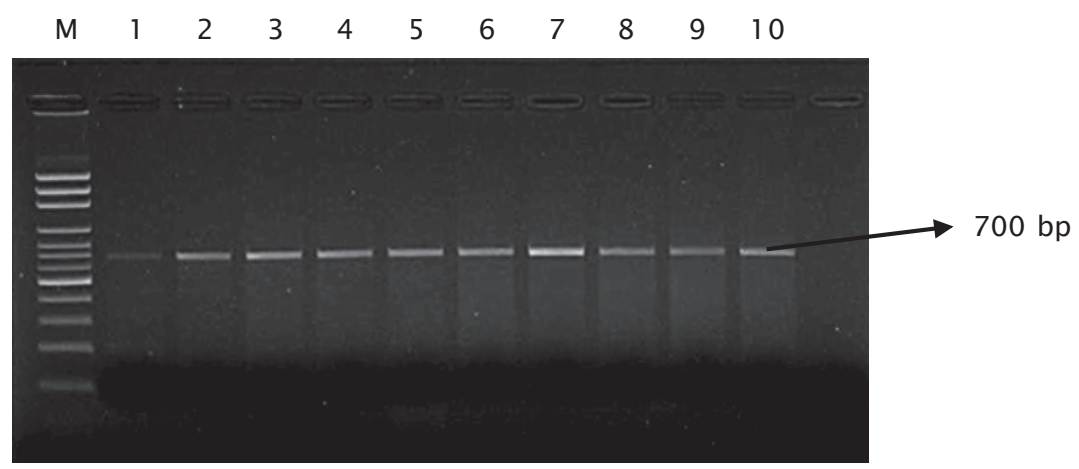

Keterangan (Note):

$\mathrm{M}=$ Marker $100 \mathrm{bp} ; 1-10=$ Sampel $($ Sample $)$

Gambar 6. Hasil amplifikasi genom DNA tiram mutiara (Pinctada maxima) dengan menggunakan primer $\mathrm{COI3}$ (F) dan $\mathrm{COI}(\mathrm{R})$

Figure 6. Results of genomic DNA amplification of pearl oyster (Pinctada maxima) by using primer $\mathrm{COI3}(F)$ and $\mathrm{COI}(R)$ 

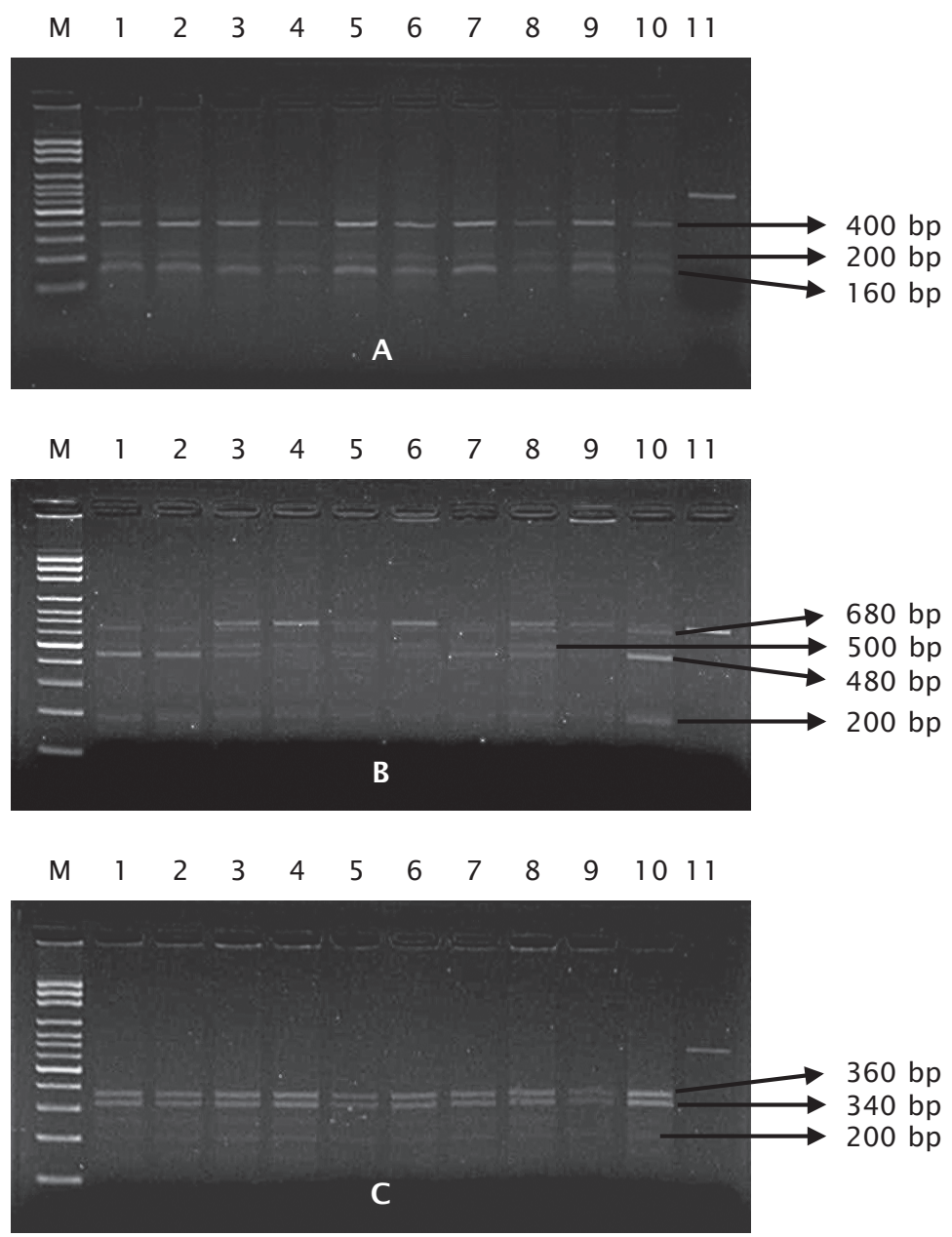

Keterangan (Note):

$M=$ Marker $100 \mathrm{bp} ; 1-10=$ Sampel (Sample); 11 = Uncut ( $P C R$ produk yang tidak dipotong dengan RE)

Gambar 7. Hasil pemotongan PCR produk induk tiram mutiara (F0) dengan menggunakan tiga jenis enzim restriksi Dde I (A), Msp I (B) dan Taq I (C)

Figure 7. Results of cutting of the PCR product of pearl oyster (FO) by using three kinds of restriction enzymes Dde I (A), Msp I (B) and Taq I (C)

Dpn II, dan Eco 090I. Dari kelima jenis enzyme tersebut, tiga di antaranya (Fox I, Hae III, dan Nla IV memberikan tipe pemotongan yang polimorfik dan ditemukan 18 jenis haplotipe yang teridentifikasi (Susilowati et al., 2009). Berdasarkan hasil analisis TFPGA, populasi Bali yang menunjukkan nilai heterozigositas paling tinggi $(0,2726)$, disusul populasi Karawang $(0,1067)$ dan Dobo paling rendah $(0,0770)$ (Tabel 4). Sementara pada populasi turunan pertama (F1) mengalami penurunan tingkat heterozigositas pada semua populasi.
Penurunan variasi genetik dari turunan pertama ( $F 1)$ yang dihasilkan dapat terjadi, disebabkan oleh beberapa faktor antara lain hilangnya beberapa alel karena induk yang digunakan saat pemijahan relatif sedikit, kemudian terbatasnya frekuensi alel yang dibawa oleh masing-masing individu baik jantan maupun betina, proses adaptasi lingkungan dan tidak adanya gen-gen unggul yang mampu meningkatkan variasi genetik (Priyono, 2000). Sementara Prasetio (2008) dalam pemantauan variasi abalon jenis Haliotis 
Tabel 3. Distribusi genotip (tipe restriksi) dari ketiga populasi tiram mutiara dengan nacre putih Table 3. Distribution of genotype from three populations of pearl oyster

\begin{tabular}{|c|c|c|c|c|c|c|c|c|}
\hline \multirow{2}{*}{$\begin{array}{l}\text { Tipe } \\
\text { enzim } \\
\text { Enzyme } \\
\text { type }\end{array}$} & \multirow{2}{*}{$\begin{array}{c}\text { Tipe } \\
\text { restriksi } \\
\text { Restriction } \\
\text { type }\end{array}$} & \multirow{2}{*}{$\begin{array}{c}\text { Ukuran fragmen } \\
\text { (pb) } \\
\text { Fragment size } \\
(b p)\end{array}$} & \multicolumn{2}{|c|}{ Bali } & \multicolumn{2}{|c|}{ Karawang } & \multicolumn{2}{|c|}{ Dobo } \\
\hline & & & F0 & $\mathrm{F} 1$ & F0 & $\mathrm{F} 1$ & Fo & $\mathrm{F} 1$ \\
\hline \multirow[t]{3}{*}{ Dde I } & A & 400 & - & - & - & - & - & 15 \\
\hline & B & 160,400 & 2 & - & - & 2 & 15 & - \\
\hline & $\mathrm{C}$ & $160,200,400$ & 13 & 15 & 15 & 13 & - & - \\
\hline \multirow[t]{4}{*}{ Msp I } & A & 200,480 & - & - & - & - & - & - \\
\hline & B & $165,200,500$ & - & - & - & - & - & - \\
\hline & $\mathrm{C}$ & $200,480,500$ & 9 & 11 & 12 & 12 & 13 & 15 \\
\hline & $\mathrm{D}$ & $200,480,500,680$ & 6 & 4 & 3 & 3 & 2 & - \\
\hline \multirow[t]{2}{*}{ TaqI } & $A$ & 340,360 & - & - & - & - & - & - \\
\hline & B & $200,340,360$ & 15 & 15 & 15 & 15 & 15 & 15 \\
\hline
\end{tabular}

Tabel 4. Nilai heterozigositas induk alam (F0) dan turunan pertama (F1) tiram mutiara dengan pemotongan tiga restriction enzyme

Table 4. Heterozygosity value of natural broodstock (FO) and first generation (F1) of pearl oyster by using three restriction enzymes

\begin{tabular}{lccc}
\hline \multirow{2}{*}{ Lokus ( Locus) } & \multicolumn{3}{c}{ Populasi Fo (Broodstock population) } \\
\cline { 2 - 4 } & Karawang & Bali & Dobo \\
\hline Dde I & 0.0000 & 0.3378 & 0.0000 \\
Msp I & 0.3200 & 0.4800 & 0.2311 \\
Taq I & 0.0000 & 0.0000 & 0.0000 \\
Heterozigositas (Heterozygosity) & 0.1067 & 0.2726 & 0.0770 \\
\hline & Populasi F1 (First & generation population) \\
\cline { 2 - 4 } & Karawang & Bali & Dobo \\
\hline Dde I & 0.1244 & 0.0000 & 0.0000 \\
Msp I & 0.3200 & 0.3911 & 0.0000 \\
Taq I & 0.0000 & 0.0000 & 0.0000 \\
Heterozigositas (Heterozygosity) & 0.0304 & 0.1481 & 0.0000 \\
\hline
\end{tabular}

asinina menyatakan bahwa kecenderungan monomorfik pada turunan pertama (F1) mengindikasikan hilangnya alel-alel penting seperti alel yang dibutuhkan dalam toleransi suhu, fungsi biomineralisasi termasuk pembentukan cangkang, fungsi pertumbuhan dan alel yang diperlukan untuk adaptasi terhadap perubahan lingkungan perairan yang diakibatkan oleh adanya variasi musim. Pada turunan F1 induk dari perairan Dobo nampak variasi genetiknya sangat rendah $(0,000)$, hal tersebut selain disebabkan oleh penggunaan induk yang sedikit, kemungkinan juga disebabkan karena induk yang dipijahkan bukan merupakan induk alam, melainkan induk hasil budidaya yang terlepas pada perairan bebas, mengingat pada perairan Dobo banyak aktivitas budidaya tiram mutiara, sehingga nampak tingkat homozigositas- 
nya tinggi pada generasi berikutnya. Dengan demikian penambahan jumlah induk yang matang gonad dalam setiap pemijahan, sangat perlu dilakukan untuk meningkatkan nilai variasi genetik turunan yang akan dihasilkan. Subaidah (1999) menyatakan bahwa dengan jumlah induk yang memijah lebih banyak dalam satu populasi, maka populasi turunan pertama (F1) akan merupakan kumpulan dari banyak variasi genetik dari induknya. Dan sebaliknya apabila induk yang memijah sedikit, maka variasi yang muncul hanya sebagian dari induk yang memijah saja. Hal tersebut didukung juga oleh pernyataan Suryani (2001), yang menjelaskan bahwa variasi genetik dalam populasi kecil yang terisolasi, seperti pada pembenihan akan terus terjadi pengurangan alel dan penurunan heterozigositas akibat aliran gen dan inbreeding depression.

Nilai keragaman populasi tiram mutiara dari tiga lokasi koleksi induk alam dari perairan di Indonesia diketahui lebih rendah dibandingkan dengan hasil penelitian Benzie et al. (2003), yang menunjukkan bahwa keragaman haplotip Pinctada maxima populasi Australia dan Indonesia berada pada kisaran 0,1290,582 . Tinggi rendahnya nilai variasi genetik pada suatu populasi sangat dipengaruhi oleh letak geografis, perbedaan salinitas dan suhu (Koehn et al., 1984) didukung oleh migrasi, seleksi, genetik drift dan karakteristik kondisi lingkungan serta mekanisme evolusi untuk bertahan hidup dan bereproduksi (Frankham et al., 2002). Sementara Blanc et al. (1996) dalam Susilowati et al. (2009). menyatakan bahwa keragaman intraspesifik, adanya perbedaan interpopulasi tiram sangat dipengaruhi oleh faktor distribusi spasialnya, karena tiram pada masa hidupnya mengalami dua proses tingkat kehidupan yaitu fase planktonik dan fase bentik, di samping itu juga dipengaruhi oleh migrasi dan seleksi alam yang menyertai pola adaptasinya. Berdasarkan dari data tersebut, dapat dikatakan bahwa induk tiram mutiara dengan karakter nacre putih dari perairan Bali dapat digunakan sebagai sumber tangkapan induk untuk dibudidayakan dan kedepan untuk meningkatkan kualitas benih perlu diterapkan manipulasi pemijahan dengan melakukan pemijahan silang. Dengan pemijahan silang, diharapkan gen-gen yang baik akan terekspresi pada generasi berikutnya dan dapat dieksplorasi untuk kepentingan budidaya yang berkelanjutan. Berdasarkan dari uraian di atas, benih yang bisa diseleksi dari hasil yang diperoleh adalah benih (F1) perairan
Bali dan benih (F1) dari perairan Dobo (Maluku). Benih-benih tersebut dipelihara lebih lanjut sampai menjadi tiram dewasa ( $\pm 1,5-2$ tahun) yang siap untuk diinsersi atau dipersiapkan sebagai calon induk.

\section{KESIMPULAN}

1. Pemijahan dengan menggunakan induk tiram dengan nacre putih, tingkat kematangan gonadnya tidak berlangsung secara seragam, dari jumlah total Induk yang ada, hanya $16 \%$ yang matang gonad dan masa inkubasi telur lebih lama dibandingkan dengan tiram pada umumnya.

2. Seleksi nacre dari benih yang diperoleh menunjukkan bahwa $48 \%$ benih memiliki nacre putih, $24 \%$ warna kuning dan warna lain sebanyak $28 \%$.

3. Keragaan genetik F0 dan F1 berdasarkan nilai heterozigositas, populasi tiram dari perairan Bali yang menunjukkan nilai keragaman yang paling baik $(0,2726)$.

\section{DAFTAR ACUAN}

Anonim. 2008. Technical guidance on pearl hatchery development in the kingdom of Tonga. Part III. Hatchery training manual for the Black Lip pearl oyster, P. margaritifera and Mabe Pearl oyster Pteria penguin, in the Kingdom of Tonga. http://www. fao.org/docrep/005/ac889e/ac889e4.

Benzie, J.A.H., Smith, C., \& Sugama, K. 2003. Mitochondria DNA reveals genetics differentiation between Australia and Indonesia Pearl oyster Pinctada maxima (James 1901) populations. Jurnal of shellfish research, 22(3): 781-787.

Bermingham, E. 1990. Mithochondrial DNA and the analysis of fish population structure. In: D.H. Withmore (Ed.), Electrophoretic and isoelectric fucosing techniques in Fisheries management. CRC Press. Inc. Buca Raton. Florida, p. 107-129.

Dhoe, S.B., Supriya, \& Juliaty, E. 2001. Biologi Tiram mutiara. Pembenihan tiram mutiara (Pinctada maxima). Balai Budidaya Laut Lampung. Juknis seri no. 6, hlm. 6-12.

Elliot, N.G. 2000. Genetic improvement programs in Abalone: what is the future?. Aquaculture Research, 31: 51-59.

Frankham, R., Ballou, J.D., \& Briscoe, D.A. 2002. Introduction to conservation genetics. Cambrige University press, 473 pp.

Hamzah, M.S. 2007. Variasi Musiman Beberapa 
Parameter Oseanografi, Kaitannya dengan Kisaran Batas Ambang Toleransi Kehidupan Kerang Mutiara (Pinctada maxima) Dari Beberapa Lokasi di Kawasan Tengah Indonesia. PROSIDING SEMINAR NASIONAL. Pusat Riset Perikanan Budidaya, Badan Riset Kelautan dan Perikanan Departemen Kelautan dan Perikanan bekerja sama dengan Jurusan Ilmu Kelautan Fakultas Perikanan dan Ilmu Kelautan Universitas Diponegoro. Semarang.

Haws, M. \& Ellis, S. 2000. Aquafarmer information sheet: collecting blac lipped pearl oyster spat. CTSA Publication no. 144.

Ito, M. 1996. Hatchery spat production of Pinctada margaritifera in Tarawa the Replublic of Kiribati. Department of Zoology. James Cook University of North Queensland, Townsville, QLD 4811 . Australia. Pearl Oyster Information Buletin. P. 8-11.

Koehn, R.K., Hall, J.G., Innes, D.J., \& Zora, A.J. 1984. Genetic differenciation of Mytilus edulis in Eastern North America. Marine Biology, 79: 117-126.

Lind, C.E., Evans, B.S., Knauer, J., Taylor, J.J.U., \& Jerry, D.R. 2009. Decreased genetic diversity and a reduced effective population size in cultured silver-lipped paerl oysters (Pinctada maxima). Aquaculture, 286: 1219.

Ovenden, J. 2000. Development of Restriction Enzymes Markers for Red Snapper (Lutjanus erythropterus and Lutjanus malabaricus) Stock Descrimination Using Genetics Variation in Mithocondrial DNA. Molecular Fisheries Laboratory. Southern Fisheries Centre. Produced For CSIRO Marine laboratories as Part of The ACIAR Indonesia Snapper Project.

Poernomo, S.H. 2008. Mengangkat mutiara yang terbenam. Majalah Samudra, Edisi 10. http://majalahsamudra.at.ua/news/200812-10-4 diakses tanggal 19 Maret 2012.

Priyono, A. 2000. Analisis isozim variasi genetik ikan bandeng (Chanos chanos Forskal) turunan 1 dan turunan 2 di kawasan perbenihan pantai Utara Bali. Tesis. Program Pascasarjana. Universitas Brawijaya. Malang, $53 \mathrm{hlm}$.

Prasetio, A.B. 2008. Variasi genetik induk abalone Haliotis asinina dari alam dan turunan pertama ( $F 1)$ dengan analisis allozyme elektroforesis. Tesis. Program Pascasarjana Universitas Brawijaya, Malang.

Rose, R.A., Dybdahl, R.E., \& Harders, S. 1990. Reproduktive cycle of the western Australian Silver Lip pearl oyster Pinctada maxima (Jameson) (Mollusca; Pteriidae). J. Shellfish Res., 9: 261-272.

Slamet, B., Tridjoko, \& Hersapto. 1997. Pengamatan aspek-aspek biologi beberapa jenis kerang mutiara (Pinctada sp.) di perairan Utara Bali. Prosiding simposium perikanan Indonesia II, hlm. 11 8-112.

Subaidah, S. 1999. Analisis variasi genetik ikan Kakap Putih (Lates calcarifer Bloch) di perbenihan dengan teknik elektroforesis. Tesis.Program Pascasarjana. Universitas Brawijaya. Malang, $53 \mathrm{hlm}$.

Suryani, S.A.M.P. 2001. Hubungan kekerabatan tiga species ikan kerapu sunu (Plectropomus spp.) atas dasar variasi genetik. Tesis. Program Pascasarjana. Universitas Brawijaya. Malang, $39 \mathrm{hlm}$.

Susilowati, R., Sumantadinata, K., Soelistyowati, D., \& Sudradjat, A. 2009. Karakteristik genetik populasi tiram mutiara (Pinctada margaritifera) terkait dengan distribusi geografisnya di perairan Indonesia. Jurnal Riset Akuakultur, 4(1): 47-52.

Supii, A.I., Sudewi, \& Rusdi, I. 2009. Penelitian pembenihan Tiram Mutiara (Pinctada maxima) dengan managemen pergantian air dan perbedaan ukuran tebar awal benih Tiram Mutiara di laut. Laporan teknis. BBRPBL Gondol Bali.

Tin Tun, M. \& Winanto. 1988. Manual of Pearl Farming on Indonesia. Balai Budidaya Laut Lampung, Lampung.

Wada, K.T. 2000. Genetic improvement of stocks of the pearl oyster. In: Fingerman, M. \& Nagabhusanam (eds). Recent Advance in Marine Biotechnology. Volume IV, Aquaculture Part A, Seaweeds and Invertebrates. Science Publisher Inc., New Hampshire, USA, p. 75-85.

Williams, S.T. \& Benzie, J.A.H. 1997. Indo-West Pacific pattern of genetic Differenciation in High-Dispersal Starfish Linckia laevigata. Mol. Ecol., 6: 559-573.

Winanto, T. 2004. Memproduksi Benih Kerang Mutiara. Penebar Swadaya. Jakarta, $95 \mathrm{hlm}$. 